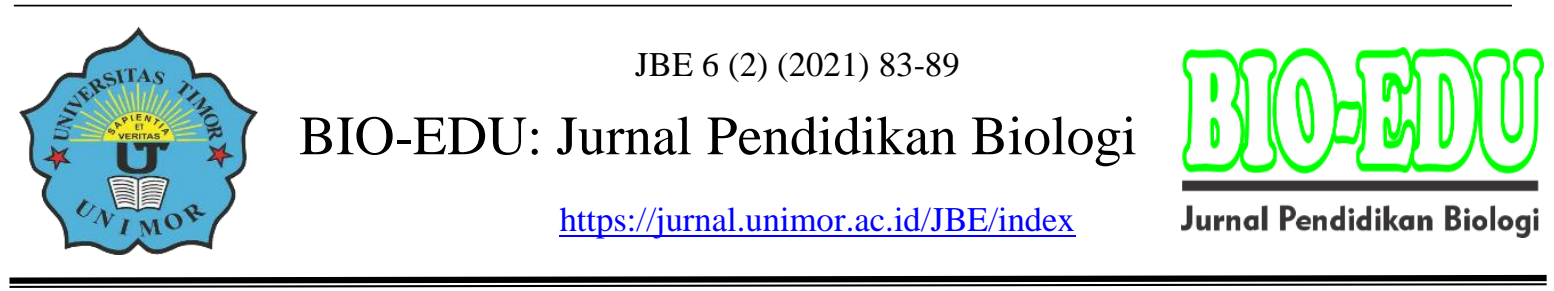

\title{
Efektivitas Bakteriosin Streptococcus thermophilus Terhadap Pertumbuhan Escherichia coli dan Staphylococcus aureus
}

\author{
Ni Made Raningsih ${ }^{1}$, Nadya Treesna Wulansari ${ }^{2}$, Ni Komang Suarnadi ${ }^{3}$ \\ ${ }^{1}$ Sekolah Tinggi Ilmu Kesehatan Buleleng, \\ ${ }^{2}$ Institut Teknologi dan Kesehatan Bali, Jalan Tukad Balian No. 180 Renon, \\ Denpasar, Bali \\ ${ }^{3}$ Sekolah Tinggi Ilmu Kesehatan Buleleng \\ *maderaningsih@gmail.com
}

DOI: $\underline{\text { https://doi.org/10.32938/jbe.v6i2.1038 }}$

\begin{abstract}
Abstrak
Kontaminasi mikroba merupakan salah satu penyebab dari berkurangnya mutu pangan yang dapat membahayakan konsumen. Bahan makanan terdiri atas protein, karbohidrat, lemak, vitamin, air dan mineral yang merupakan medium yang baik bagi pertumbuhan mikroba sehingga dengan mudah difermentasi. Pemberian bahan pengawet berupa thermophilin yang bersumber dari Streptococcus thermophilus dapat dilakukan untuk mengatasi kontaminasi mikroba pada bahan pangan. Penelitian ini bertujuan untuk mengetahui efektivitas pemberian bakteriosin Streptococcus thermophilus dengan konsentrasi yang berbeda terhadap E. coli dan $S$. aureus. Penelitian ini adalah true experiment yang dilakukan di laboratorium Mikrobiologi Teknologi Pangan Universitas Udayana. Pengujian efektivitas bakteriosin dengan metode difusi agar dengan kertas cakram. Diameter zona bening diukur dengan jangka sorong. Zona hambat dihitung secara vertikal dan horizontal, dikurangi dengan diameter kertas cakram kemudian dirata-ratakan. Analisis data menggunakan Anava satu arah dan uji lanjut Duncan 5\%. Hasil penelitian menunjukkan bakteriosin yang diisolasi dari S. thermopilus efektif menghambat pertumbuhan E. coli dan $S$. aureus pada konsentrasi $100 \%$ dengan daya hambat pada E.coli $14 \mathrm{~mm}$ dan pada S. aureus $15 \mathrm{~mm}$.
\end{abstract}

Kata Kunci: Efektivitas, Bakteriosin, Streptococcus thermophilus, Escherichia coli, Staphylococcus aureus

\begin{abstract}
Microbial contamination is one of the causes of reduced food quality that can harm consumers. Foodstuffs consist of protein, carbohydrates, fats, vitamins, water and minerals which are a good medium for microbial growth so that they are easily fermented. Provision of preservatives in the form of thermophilin sourced from Streptococcus thermophilus can be done to overcome microbial contamination in food ingredients. This study aims to determine the effectiveness of Streptococcus thermophilus bacteriocin with different concentrations against E. coli and S. aureus. This research is a true experiment conducted in the Microbiology Laboratory of Food Technology, Udayana University. Testing the effectiveness of bacteriocin by agar diffusion method with disc paper. The diameter of the clear zone was measured with a caliper. The zone of inhibition was calculated vertically and horizontally, reduced by the diameter of the disc paper and then averaged. Data analysis used one-way ANOVA and Duncan's 5\% follow-up test. The results showed that the bacteriocin isolated from S. thermopilus effectively inhibited the growth of E. coli and S. aureus at a concentration of $100 \%$ with inhibition on E.coli $14 \mathrm{~mm}$ and S. aureus $15 \mathrm{~mm}$.
\end{abstract}

Keywords: Effectiveness, Bacteriocin, Streptococcus thermophilus, Escherichia coli, Staphylococcus aureus 


\section{PENDAHULUAN}

Mikroba merupakan salah satu makhluk hidup uniseluler yang habitatnya tersebar luas di alam. Keberadaan mikroba dapat menyebabkan adanya interaksi antarmikoba interaksi antarmikroba baik bersifat sinergis ataupun antagonis. Interaksi yang bersifat sinergis memberikan dampak positif bagi mikroba yang lain. Sedangkan interaksi yang bersifat antagonis berarti mikroba memberikan dampak negatif bagi mikroba yang lain, seperti menghambat pertumbuhan dengan menghasilkan metabolit sekunder.

Kemampuan dari interaksi mikroba tersebut dapat dimanfaatkan dalam berbagai bidang. Seperti misalnya membusuknya bahan makanan yang disimpan dalam jangka waktu lama (Tshikantwa dkk. ,2018). Jenis mikroba yang sering ditemukan pada makanan yang berprotein tinggi yaitu Staphylococcus aureus. Mikroba ini dapat ditemukan di air, debu, udara yang menyebabkan kemungkinan besar mengkontaminasi bahan makanan.Selain itu $S$. aureus juga menghasilkan enterotoksin merupakan senyawa beracun (Arief, 2017). Mikroba lain yang sering ditemukan di lingkungan sekitar seperti air yang dikonsumsi patut dicurigai mengandung jenis mikroba Escherichia coli yang dalam jumlah berlebihan dapat menyebabkan diare (Tanto C, 2014). Dengan demikian perlu diadakan pengendalian pertumbuhan kedua mikroba yang bersifat kosmopolit tersebut.

Kontaminasi mikrobiologis merupakan salah satu penyebab dari berkurangnya mutu pangan yang dapat membahayakan konsumen (Pudjirahaju, 2017). Bahan makanan terdiri atas protein, karbohidrat, lemak, vitamin dan mineral yang merupakan medium yang baik bagi pertumbuhan mikroba sehingga dengan mudah difermentasi (Pelczar and Chan, 2009). Pemberian bahan pengawet berupa zat antimikroba dapat dilakukan untuk mengatasi masalah tersebut (Silva dkk.,2018). Pada umumnya bahan pengawet untuk mengawetkan pangan mempunyai sifat mudah rusak. Bahan ini ini dapat menghambat atau memperlambat proses fermentasi atau penguraian yang disebabkan oleh mikroba (Cahyadi, 2008). Bahan pengawet dapat dibagi menjadi pengawet alami dan sintetik. Pengawet alami biasanya berasal dari jenis rempahrempah. Sedangkan bahan pengawet sintetik dapat bersifat organik dan anorganik. Saat ini masih banyak ditemukan penggunaan bahan pengawet yang sudah dilarang penggunaanya seprti formalin dan boraks (Naufalin, 2019).

Hal yang dapat dilakukan untuk mengatasi hal tersebut dengan menyediakan pengawet alami. Selain menggunakan bahan rempah-rempah, pengembangan bahan pengawet alami telah terarahkan melalui pemanfaatan mikroorganisme seperti alga dan bakteri (Jun Mei,2019). Pengawetan bahan pangan secara mikrobiologis yaitu dengan cara menambahkan mikroba seperti bakteri asam laktat (Silva dkk., 2018). Sifat terpenting dari bakteri asam laktat yaitu kemampuannya dalam merombak senyawa kompleks menjadi senyawa lebih sederhana sehingga dihasilkan asam laktat. Hasil dari asam laktat berjalan cepat sehingga menyebabkan pertumbuhan mikroba terhambat. Selain itu bakteri asam laktat menghasilkan senyawa metabolit seperti bakteriosin yang bersifat antimikroba (José, 2020). Nilai strategis penggunaan metabolit berupa bakteriosin dari bakteri asam laktat sebagai bahan pengawet makanan adalah bersifat antimikroba, dapat berfungsi sebagai probiotik, dan bersifat non-toksik (LeneveuJenvrin dkk., 2019) Berdasarkan hal tersebut maka dilakukan penelitian tentang metabolit yang diproduksi oleh bakteri asam laktat Streptococcus thermophilus untuk menghambat pertumbuhan E.coli dan S. aureus yang digunakan sebagai parameter dengan menggunakan konsentrasi yang berbeda. 


\section{METODE}

Jenis penelitian ini merupakan true experiment menggunakan Rancangan Acak Lengkap (RAL) dengan 10 perlakuan dan 3 kali pengulangan. Penelitian ini dilakukan di laboratorium mikrobiologi Teknologi Pangan Universitas Udayana. Sampel $S$. thermophilus diperoleh dari Laboratorium Biosains Universitas Udayana. Alat dan bahan yang digunakan yaitu isolat $S$. thermophilus, E.coli dan S.aureus, $\mathrm{NaCl} 0,9 \%$, alcohol, media MRS (de Man Rogosa Sharpe), media MHA (Mueller Hinton Agar), alkohol, $\mathrm{NaOH} 1 \mathrm{~N}$, akuades, cawan petri, vortex, inkubator, autoklaf, mikro pipet, kertas cakram, jangka sorong,tabung reaksi, kapas, filter. Adapun tahapan ekstraksi bakteriosin dan uji aktivitas antibakteri bakteriosin adalah sebagai berikut.

\section{Ekstraksi Bakteriosin dari Streptococcus thermophilus}

Ekstraksi bakteriosin dilakukan dengan menumbuhkan bakteri Streptococcus thermophilus pada media MRS cair sebanyak $5 \mathrm{~mL}$. Setelah bakteri diinokulasikan pada media MRS, selanjutnya divortex hingga homogen dan diinkubasi selama 1 x 24 jam pada suhu $32^{\circ} \mathrm{C}$. Kultur cair disentrifugasi dengan kecepatan 10.000 RPM (Rotary per Minute) pada suhu $4^{\circ} \mathrm{C}$ selama 15 menit. Filtrat dinetralkan hingga $\mathrm{pH} 7,0$ menggunakan $\mathrm{pH}$ meter dengan menambahkan larutan $\mathrm{NaOH} 1 \mathrm{~N}$. Filtrat disterilkan dengan filter bakteri berdiameter $0,22 \mu \mathrm{m}$ ke dalam tabung steril untuk memperoleh supernatan antibakteri (Usmiati \& Mawarti, 2007).

\section{Uji Aktivitas Antibakteri Bakteriosin}

Uji aktivitas antibakteri bakteriosin menggunakan metode difusi agar. Supernatan antibakteri dibuat dengan konsentrasi 10\% hingga 100\% dengan 3 kali pengulangan dalam setiap konsentrasi. Untuk membuat konsentrasi dilakukan dengan cara pengenceran menggunakan larutan fisiologis $\mathrm{NaCl} 0,9 \%$. Selanjutnya, setiap konsentrasi supernatant diambil sebanyak $20 \mu \mathrm{L}$ lalu diteteskan pada kertas cakram steril berdiameter $5 \mathrm{~mm}$. Kertas cakram diletakkan diatas media MHA yang mengandung $200 \mu \mathrm{L}$ bakteri indikator (E.coli dan S.aureus) diinkubasi selama 24 jam suhu $37^{\circ} \mathrm{C}$. Diameter zona bening diukur dengan jangka sorong. Zona hambat dihitung secara vertikal dan horizontal, dikurangi dengan diameter kertas cakram kemudian dirata-ratakan (Deslianri dkk., 2016).

\section{Analisis Data}

Analisis data menggunakan Anava satu arah dan uji lanjut Duncan dengan taraf signifikansi 5\% dengan menggunakan aplikasi SPSS 20.

\section{HASIL DAN PEMBAHASAN}

Aktivitas daya hambat Bakteriosin dari S. thermophilus Terhadap E. coli dan $S$. aureus ditunjukkan oleh tabel 1 berikut.

Tabel 1. Rata-Rata Daya Hambat S. thermophilus Terhadap E. coli dan S. aureus

\begin{tabular}{|c|c|c|c|c|c|}
\hline No. & Konsentrasi v/v & $\begin{array}{c}\text { E. coli } \\
(\mathbf{m m})\end{array}$ & Pvalue & S.aureus $(\mathrm{mm})$ & Pvalue \\
\hline 1 & $10 \%$ & $4 \pm 0,66$ & & $6 \pm 0,26$ & \\
\hline 2 & $20 \%$ & $5 \pm 0,36$ & & $6 \pm 0,36$ & \\
\hline
\end{tabular}




\begin{tabular}{|c|c|c|c|c|c|}
\hline No. & Konsentrasi v/v & $\begin{array}{c}\text { E. coli } \\
\text { (mm) }\end{array}$ & Pvalue & S.aureus $(\mathrm{mm})$ & Pvalue \\
\hline 3 & $30 \%$ & $5 \pm 0,20$ & \multirow{9}{*}{0,000} & $8 \pm 0,36$ & \multirow{9}{*}{0,000} \\
\hline 4 & $40 \%$ & $7 \pm 0,17$ & & $7 \pm 0,36$ & \\
\hline 5 & $50 \%$ & $9 \pm 0,62$ & & $10 \pm 1,13$ & \\
\hline 6 & $60 \%$ & $11 \pm 0,36$ & & $10 \pm 0,26$ & \\
\hline 7 & $70 \%$ & $11 \pm 0,20$ & & $12 \pm 0,62$ & \\
\hline 8 & $80 \%$ & $12 \pm 0,75$ & & $12 \pm 0,36$ & \\
\hline 9 & $90 \%$ & $13 \pm 0,36$ & & $15 \pm 1,08$ & \\
\hline 10 & $100 \%$ & $14 \pm 0,36$ & & $15 \pm 0,36$ & \\
\hline 11 & Kontrol & $0 \pm-$ & & $0 \pm-$ & \\
\hline
\end{tabular}

Data pada tabel 1 menunjukkan, semakin besar konsentrasi dari bakteriosin yang dihasilkan oleh S.thermophillus, maka semakin besar diameter zona hambatnya. Berdasarkan uji statististik Anava satu arah menunjukkan nilai $p$ value sebesar $0,000<$ 0,005 , sehingga dapat disimpulkan terdapat pengaruh pemberian berbagai konsentrasi bakteriosin S.thermophillus. Hasil uji lanjut yaitu uji Duncan menunjukkan konsentrasi yang paling efektif adalah pada konsentrasi $100 \%$ bakteriosin S.thermophillus memiliki daya hambat sebesar $14 \mathrm{~mm} \pm 0,36$ dan $15 \mathrm{~mm} \pm 0,36$ berturut-turut terhadap bakteri E.coli dan S.aureus. Hal ini menunjukkan bahwa bakteriosin yang dihasilkan oleh bakteri S.thermophillus mampu menghambat pertumbuhan bakteri E.coli dan S.aureus.

Kemampuan bakteriosin dalam menghasilkan daya hambat tergantung dari konsentrasi bakteriosin dan jenis bakteri patogen. Hasil penelitian ini sejalan dengan penelitian yang dilakukan oleh Aslam dkk. (2011) yang menyatakan bahwa bakteriosin S.thermophillus mampu menghambat bakteri gram positif seperti S. aureus, B. subtilis dan bakteri gram negatif seperti E. coli, Pasteurella multocida. Pada penelitian ini, daya hambat yang dihasilkan terhadap bakteri E.coli dan S.aureus berbeda. Hal ini dapat disebabkan oleh perbedaan struktur penyusun dinding sel antara bakteri Gram positif dan Gram negatif (Sari dkk., 2018). Bakteri Gram positif tersusun atas membran tunggal yang dilapisi peptidoglikan yang tebal. Selain itu dinding sel bakteri Grampositif memiliki asam Teikoat dan Teikuronat. Pada bakteri Gram negatif tersusun atas membran ganda dengan peptidoglikan yang tipis terletak antara membrane luar dan membrane dalam. Pada bagian membran luar mengandung lipopolisakarida. Sehingga bakteri Gram negatif memiliki ketahanan yang lebih kuat dibandingkan bakteri Gram positif (Silhavy dkk.,2010).

Jenis bakteriosin yang dihasilkan oleh setiap jenis bakteri asam laktat memiliki aktivitas antibakteri yang berbeda-beda. Penelitian yang dilakukan oleh Mezaini dkk. (2009) hermophilin atau bakteriosin yang dihasilkan dari S. thermophilus memiliki sifat peptidik,tahan terhadap panas, stabil pada kisaran $\mathrm{pH}$ yang luas, selain itu thermophilin yang dihasilkan dari $S$. thermophilus mampu menghambat pertumbuhan bakteri Gram negatif dan Gram positif . Bakteriosin merupakan protein ekstraseluler yang memiliki aktivitas yang mampu menghambat pertumbuhan bakteri Gram positif maupun Gram negatif (Sari dkk., 2018). Lee an Kim (2011) menyatakan bahwa bakteriosin merupakan peptide yang memiliki aktivitas antibakteri sempit yang utamanya menghambat bakteri lain yang memiliki hubungan kekerabatan dekat dengan bakteri penghasilnya. Mekanisme dari beberapa jenis bakteriosin berbeda-beda tergantung dari jenis bakteri penghasilnya. Kemampuan bakteriosin dalam menghambat bahkan mematikan bakteri 
dapat dengan penghambatan sintesis peptidoglikan, pembentukan pori dan degradasi sel DNA (Todorov, dkk., 2011).

Penelitian yang dilakukan oleh Yi et al. (2016) melakukan pengamatan menggunakan transmission electron microscopy (TEM) pengaruh bakteriosin Lactobacillus crustorum yang diberikan pada S. aureus. Hasil pengamatan setelah pemberian bakteriosin selama 30 menit yaitu dinding sel tampak menipis, muncul lapisan seperti duri di sekitar dinding luar, septum menjadi tidak jelas, dan hanya sebagian membran sitoplasma yang masih tampak jernih. Ini menunjukkan bahwa struktur dinding sel dan membran sitoplasma bakteri $S$. aureus dapat terpengaruh oleh pemberian bakteriosin yang diikuti dengan hilangnya kandungan di dalam sel. Perlakuan pemberian bakteriosin selanjutnya selama 2 jam menunjukkan membran seperti mesosom meregang ke dalam sitoplasma. Kerusakan sel tersebut yang menyebabkan kematian sel S.aureus. Selain itu, mampu melakukan penghambatan biosintesis dinding sel dan aktivitas enenzim (RNase atau DNAse) dalam sel target (Chotiah, 2013).

Pemanfaatan bakteriosin kedepannya mampu digunakan sebagai pengawet alami pada pangan serta mengendalikan foodborne pathogen secara alami. Patrovsky dkk. (2016) menyebutkan bahwa bakteriosin memiliki sifat yang menguntungkan sebagai antibakteri. Bakteriosin yang berasal dari bahan alami bersifat minim toksik, termostabil, enzim pencernaan mudah mendegradasikannya. Selain itu, penggunaan bakteriosin juga tidak menimbulkan bau serta perubahan rasa pada produk pangan. Hal inilah yang membuat pemanfaatan bakteriosin perlu dikembangkan sebagai pengawet alami pada produk pangan.

\section{KESIMPULAN DAN SARAN}

\section{Kesimpulan}

Bakteriosin yang diisolasi dari S. thermopilus efektif menghambat pertumbuhan E. coli dan S. aureus pada konsentrasi $100 \%$ dengan daya hambat pada E.coli $14 \mathrm{~mm}$ dan pada $S$. aureus $15 \mathrm{~mm}$. Daya hambat terendah bakteriosin yang diisolasi dari S. thermopilus terhadap pertumbuhan E. coli dan S. aureus pada konsentrasi $10 \%$. Penelitian ini diharapkan dapat menjadi bahan acuan dalam penelitian lebih lanjut dalam memproduksi pengawet hayati untuk menekan pertumbuhan bakteri patogen pada bahan pangan.

\section{Saran}

Saran yang dapat diberikan dalam penelitian ini adalah perlu dilakukan penelitian lebih lanjut mengenai MIC (Minimum Inhibitory Concentration) bakteriosin $S$. thermopilus.

\section{DAFTAR RUJUKAN}

Abrams, D., Barbosa, J., Albano, H., Silvia, J., Gibbs, P.A., Teixeira,P. (2011). Characterization of bacPPK34 a bacteriocin produced by Pediococcus pentosaceous strain K34 isolated from "Alheira". Food Control 22(6): 940-946.

Arief, Irma Isnafia. 2017. Prevention of Staphylococcus aureus Contamination On Animal Products Using Indonesian Natural Products. http://dx.doi.org/10.5772/66045 
Aslam.M., Shahid, M., Rehman,F.U., Naveed,N.H., Batool, A.I., Sharif,S. Asia A.. (2011). Purification and characterization of bacteriocin isolated from Streptococcus thermophiles. African Journal of Microbiology Research. 5(18) : 2642-2648.

Chotiah, S. (2013). Potensi Bakteriosin Untuk Kesehatan Hewan Dan Keamanan Bahan Pangan. Balai Besar Penelitian Veteriner. Bogor.

Deslianri, L., Sari, R., Apridamayanti, P. (2016). Identifikasi Bakteri Asam Laktat (BAL) penghasil bakteriosin dari minuman Ce hun tiau yang memiliki aktivitas antibakteri terhadap bakteri patogen. Pharmaceutical Science and Research, $3(2)$.

Ekawati E.R. 2016. Buku Ajar Bakteriologi 3. Surabaya

José Aníbal Mora-Villalobos , Jéssica Montero-Zamora , Natalia Barboza, Carolina Rojas-Garbanzo, Jessie Usaga, Mauricio Redondo-Solano, Linda Schroedter, Agata Olszewska-Widdrat , José Pablo López-Gómez.2020. Multi-Product Lactic Acid Bacteria Fermentations: A Review. Fermentation 6, 23; doi:10.3390/fermentation6010023.

Jun Mei, Xuan Ma,Jing Xie.2019. Review on Natural Preservatives for Extending Fish Shelf Life. Foods 8, 490; doi:10.3390/foods8100490

Lee, H.J., Kim, H.Y. (2011). Lantibiotics, class I bacteriocins from the genus Bacillus J Microbiol Biotechnol. 21(3): 229-235.

Leneveu-Jenvrin, C.; Charles, F.; Barba, F.J.; Remize, F. 2019. Role of biological control agents and physical treatments in maintaining the quality of fresh and minimally-processed fruit and vegetables. Crit. Rev. Food Sci. Nutr, 1-19. [CrossRef] [PubMed]

Mezaini,A.,Nour-Eddine C.,Abdelkader Dilmi B.,Naima Nedjar-Arroume, Jean Pierre H. 2009. Antibacterial Activity of Some Lactic Acid Bacteria Isolated from an Algerian Dairy Product. Journal of Environmental and Public Health, Article ID 678495, 6 pages doi:10.1155/2009/678495

Naufalin,Rifda. 2019.Natural Preservation Opportunities and Challenges In Improving Food Safety. AIP Conference Proceedings 2094 ; https://doi.org/10.1063/1.5097501

Patrovsky M, Kourimska L, Havlikova S, Markova J, Pechar R, Rada V. 2016. Utilization of bacteriocin-producing bacteria in dairy products. Mljekarstvo 66(3): 215-224.

Pudjirahaju, Astuti. 2017. Pengawasan Mutu Pangan. Pusat Pendidikan Sumber Daya Manusia Kesehatan.

Rossi, F., Marzotto, M., Cremonese, S, Rizzotti, L, Torriani, S. Diversity of Streptococcus thermophilus in bacteriocin production; inhibitory spectrum and occurrence of thermophilin genes. Food Microbiol. 35(1):27-33.

Sari, R., Apridamayanti, P. Octaviani, M. (2018). Optimization of Bacteriocin Activity Produced by Lactobacillus plantarum Bacteria from Ce Hun Tiau Beverages. Pharmaceutical Sciences and Research, 5(1), 1-6. 
Silhavy ,Thomas J., Daniel Kahne, and Suzanne Walke. 2010. The Bacterial Cell Envelope. Cold Spring Harb Perspect Biol ;2:a000414

Silva, G.C. Celia, Sofia P.M. Silva,Susana C. Ribeiro. 2018. Application of Bacteriocins and Protective Cultures in Dairy Food Preservation. Front. Microbiol.,https://doi.org/10.3389/fmicb.2018.00594

Tanto C. Diare. Dalam: Tanto C, editor. Kapita selekta kedokteran: essentials of medicine IV. Jakarta: Media Aesculapius; 2014. hlm. 65-9

Todorov, S.D., Rachman, C., Fourrier, A., Dicks, L.M.T., Reenen, C.A., Prevost, N., Dousset X. 2011. Characterization of a bacteriocin produced by Lactobacillus sakei R1333 isolated from smoked salmon. Anaerobe. 17: 23-31.

Tshikantwa ,Tiroyaone Shimane, Muhammad Wajid Ullah, Feng He, Guang Yang. 2018. Current Trends and Potential Applications of Microbial Interactions for Human Welfare.

Frontiers Microbiol., https://doi.org/10.3389/fmicb.2018.01156

Usmiati, S., T. Marwati. (2007). Seleksi dan Optimasi Proses Produksi Bakteriosin dari Lactobacillus sp. J. Pascapanen. 4(1): 27-37.

Yi L, Dang Y, Wu J, Zhang L, Liu X, Liu B, Zhou Y, Lu X. 2016. Purification And Characterization Of A Novel Bacteriocin Produced By Lactobacillus crustorum MN047 Isolated Froum Koumiss From Xinjiang, China. J Dairy Sci 99(9): 7002-7015 